\title{
A busca de um jornalista, professor e pesquisador pela origem do Jornalismo na Bacia do Rio da Prata
}

DOI: $10.1590 / 1809-58442016113$

\author{
Ricardo Henrique Almeida Dias \\ (Centro Universitário Unifacvest, Pró-Reitoria Acadêmica, \\ Curso de Jornalismo. Lages-SC, Brasil)
}

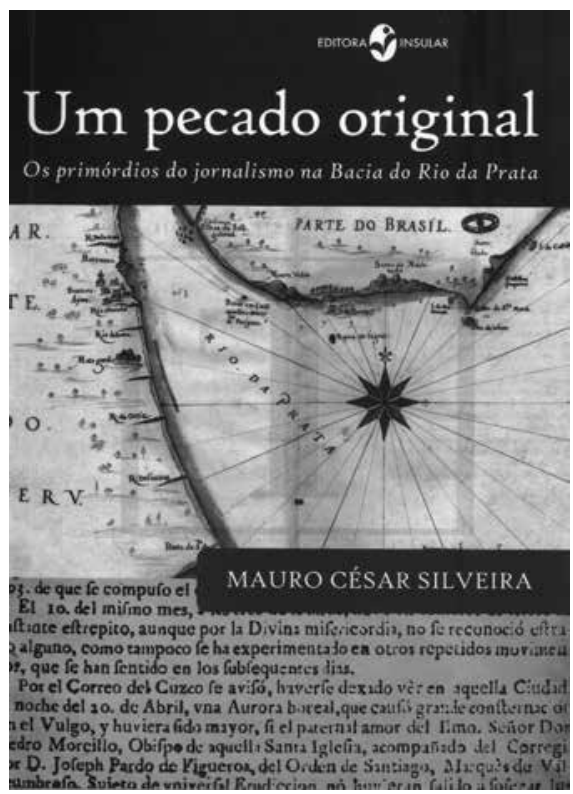

SILVEIRA, Mauro César. Um pecado original: os primórdios do jornalismo na Bacia do Rio da Prata. Florianópolis: Insular, 2014. 160 p.

Jornalista e professor pesquisador do curso de Jornalismo da Universidade Federal de Santa Catarina, Mauro César Silveira em seu novo livro, intitulado Um pecado original: os primórdios do jornalismo na Bacia do Rio da Prata (Insular, 2014), buscou investigar os primórdios da imprensa no Cone Sul (área que abrange o Brasil, Argentina, Paraguai e Uruguai).

Silveira, com grande experiência em estudos históricos, já que também é autor de obras como A batalha de papel: a charge como arma na guerra contra o Paraguai (Editora da UFSC, 2010) e Adesão Fatal: a participação portuguesa na Guerra do Paraguai (Edipucrs, 2003), optou pela metodologia que estabelece como fio condutor da pesquisa a relação entre fatos ligados a processos em diferentes lugares da mesma área geográfica. Tal metodologia é fruto das novas possibilidades abertas pela Nova História, que se vale de diferentes fontes para a pesquisa historiográfica, como documentos oficiais, relatos em correspondências pessoais, dados estatísticos, fragmentos de jornais, dentre outras fontes. Assim, antes de se debruçar sobre os primórdios do Jornalismo na Bacia do Prata, o autor buscou traçar um panorama histórico da história da Espanha a partir da consolidação do governo centralizado, com os "reis católicos", em 1479. 
A jornada historiográfica de Silveira começa com a busca da unificação da península ibérica pelos monarcas de Castela e Aragão, região até então constituída de um mosaico de reinos, principados e baronatos, contando ainda com a presença muçulmana na Andaluzia. Com o casamento entre Isabel de Castela e Fernando de Aragão, os reinos que estes representavam se uniram. De acordo com Silveira, a atuação de Isabel e Fernando foi bem mais além da união dinástica das duas coroas. "A afinidade entre os dois resultou numa obstinada campanha visando à constituição de um estado nacional, tendo como horizonte maior a monarquia absoluta" (p.20). Além da busca pela unificação, a Igreja contou com um papel importante no apoio político a aliança, já que tinha por objetivo a expulsão dos muçulmanos da península e da instauração e consolidação do Tribunal da Inquisição.

Após se dedicar ao estudo da situação política espanhola nos séculos 15, 16 e 17, Silveira passou a focar no surgimento da imprensa na região, a partir dos avisos e cartas até a fundação da Gazeta de Madrid, em 1661, por Juan José de Áustria, filho bastardo do rei Felipe IV com a atriz María Inés Calderón. Juan José percebeu a importância da informação para o exercício do poder e concebeu a edição para circulação mensal com quatro páginas. Com o tempo, a publicação foi ganhando cada vez mais caráter oficial até se transformar no diário oficial do país. Já o século 18, com o estabelecimento da dinastia bourbônica, representou um período de estabelecimento definitivo da imprensa, com a criação de novas publicações quinzenais, semanais e diárias. O primeiro diário espanhol surgiu em 1758 e começou a ser chamado de Diario Noticioso a partir da terceira edição. Apesar da diversidade de edições, todas elas estavam sobre forte vigilância do Estado, a partir dos princípios de afirmação do sistema monárquico e a defesa da fé católica. A Inquisição espanhola recolhia todas as publicações que eram classificadas como perniciosas. Entretanto, houve um estímulo à difusão dos conhecimentos avaliados como úteis para o progresso do reino. Isso durou até os desdobramentos da revolução francesa, em 1789, o que levou, em 1791, ao fechamento dos mais importantes periódicos do país devido ao temor de uma "epidemia revolucionária".

Após o delineamento do surgimento da imprensa na Espanha, o autor passou então a se dedicar ao surgimento do Jornalismo na América Latina. As publicações criadas na América Espanhola se caracterizaram pela forte restrição à circulação, exercida pelos monarcas espanhóis e pela Igreja Católica. Características que motivaram Silveira a batizar sua obra como Um pecado original.

As primeiras impressões de livros com a temática religiosa aconteceram no século 16, no atual México e Peru. Embriões de Jornalismo em formas de avisos tiveram por objetivo satisfazer as necessidades dos colonos em saber o que ocorria na metrópole nos séculos 16 e 17. “A grande novidade do início dos seiscentos eram boletins com informações breves 
e de caráter internacional, que incluíam anúncios publicitários copiados de impressos que circulavam na península ibérica” (p.111). Em 1715, é impresso o primeiro número de Gazeta de Lima, uma reprodução integral da oficial Gazeta de Madri. O relançamento da Gazeta de Lima, em 1744, com notícias locais, é considerado o primeiro periódico da América do Sul.

Em 1776, com a criação do Vice-Reino do Rio da Prata, com sede em Buenos Aires, o Jornalismo na região tomou novo rumo. Em 1801, é lançado o periódico Telégrafo mercantil, rural, político, econômico e historiógrafo del Río de La Plata - considerado como marco do nascimento do Jornalismo no Cone Sul. O Telégrafo mercantil foi concebido pelo espanhol Francisco Antonio Cabello y Mesa, com o apoio do Manuel Belgrano, que ocupava o poderoso cargo de secretário do Real Consulado do Comércio no Vice-Reino do Rio da Prata. O objetivo maior do periódico era divulgar o pensamento ilustrado cristão e recebeu apoio dos demais homens influentes do Rio da Prata. Aos poucos, no entanto, se afastou desse objetivo, passando a incluir alguns textos críticos e satíricos. A ousadia teve preço, já que foi suspensa pela administração regional. Belgrano, nove anos depois, criou o Correo de Comercio, uma publicação eficaz na mobilização dos criollos argentinos, exigindo condições mais favoráveis da monarquia espanhola. Essa publicação teve papel decisivo na articulação da Revolução de Maio, que deu início ao processo que culminaria, alguns anos depois, em 1816, com a independência das Províncias Unidas do Rio da Prata. O jornal foi um precursor dos periódicos que passariam a atuar com um viés libertador, emancipacionista, na segunda década do século 19. “As barreiras seculares que inibiam o desenvolvimento da atividade jornalística haviam sido, finalmente, rompidas” (p.152).

Um pecado original: os primórdios do jornalismo na Bacia do Rio da Prata se constitui em uma leitura obrigatória a todos os historiadores da mídia, professores e estudantes de história do Jornalismo. Boa leitura.

\section{Ricardo Henrique Almeida Dias}

Doutor em Educação pela FE/Unicamp (2015). Jornalista formado pelo curso de Comunicação Social habilitação em Jornalismo pela Universidade Federal de Mato Grosso do Sul (2006). Mestre em Educação (2009) pela Faculdade de Educação (FE) da Universidade Estadual de Campinas (Unicamp). Atualmente, é docente do curso de Jornalismo do Centro Universitário Unifacvest - Lages/ SC. E-mail: rhad@mail.br. 